pÿBABEL7: Crustal Scale Extension Associated with the Formation of the Baltic Sea Paleorift, Fennoscandian Shield

\title{
Korja, Annakaisa
}

Wiley Blackwell

2018

pÿKorja , A \& Heikkinen , P J 2018 , BABEL7: Crustal Scale Extension Associated with the Formation of the Baltic Sea Paleorift, Fennoscandian Shield . in A A Misra \& S Mukherjee (eds) , Atlas of Structural Geological Interpretation from Seismic Images . 1. edn , Wiley Blackwell , Chichester , pp. 201-203 . https://doi.org/10.1002/9781119158332.ch39

http://hdl.handle.net/10138/236990

https://doi.org/10.1002/9781119158332.ch39

cc_by

publishedVersion

Downloaded from Helda, University of Helsinki institutional repository.

This is an electronic reprint of the original article.

This reprint may differ from the original in pagination and typographic detail.

Please cite the original version. 


\section{BABEL7: Crustal-Scale Extension Associated with the Formation of the Baltic Sea Paleorift, Fennoscandian Shield Annakaisa Korja* and Pekka Heikkinen}

University of Helsinki, Finland

*annakaisa.korja@helsinkifi

BABEL profiles image the crustal structures of the Fennoscandian Shield (BABE., Working Group, 1993; Korja et al., 2006). BABEI.7 (Figure 39.1a) images crustal-scale extension associated with formation of the Baltic Sea paleorift and intrusion of the Aland rapakivi granite batholith (Korja and Heikkinen, 1995; 2005). The Baltic Sea is a Mesoproterozoic failed rift associated with thinning of the crust, voluminous bimodal magmatism (rapakivi granites and gabbro-anorthosites) and continental type sedimentary basins. Rapakivi granite plutons are characteristically multiple intrusions emplaced in an extensional tectonic setting as relatively shallow-level plutons (Kohonen and Rämö, 2005).

The near vertical seismic reflection data are the final stacks from BABEL7 (Figure 39.1b). Acquisition parameters and the full processing sequence have been described by the BABEI. Working Group (1993). Migrated sections are displayed as instantaneous amplitude sections overlain by automatic line drawings (Korja and Heikkinen, 2005). The section is plotted without normalization, that is, the amplitudes of the different areas in each section are comparable. The large-scale reflectivity changes are pronounced, whereas the details of individual reflections are obscured.

Geological interpretation presumes that reflections image mainly primary igneous or secondary tectonic contacts formed during deformation. Weak reflectivity generally indicates monotonous intrusions and older crustal pieces in which the internal structure has been homogenized in the scale of reflectivity before deforming.

BABEL7 profile images three major blocks with distinct reflectivity patterns. The upper crust of the eastern part is weakly reflective but it hosts some minor reflections mimicking graben-horst and diamondshaped structures. The western upper and middle crust is characterized by strong southeast-dipping bands of crustal-scale listric reflections flattening at the middlelower crust boundary. 'The lower crust is highly reflective and bulges upwards in the east. The reflection Moho, defined as base of the reflective lower crust, is distinct and can be correlated with the Moho derived from the wide-angle data.

The crustal structure is interpreted to image mostly the latest tectonic extensional event associated with the thinning of the crust and the formation of the $\AA$ land and Gävle rapakivi granite batholiths and Bothnian Sea Basin. Some of the extensional normal faults may be inverted stacking surfaces.

The listric reflections are interpreted to image listric normal faults detaching on the mid-lower crust boundary. The offsets of the major reflections can be traced to the surface, where they presumably connect with thin-skin half-grabens of the Bothnian Sea. Thinning of the upper-middle crust counterbalance by bulging and uplifting of the lower crust. Space created by extension is occupied by the Aland batholith: a homogenous and weakly reflective body. It is composed of an upper granitic part $\left(6.15 \mathrm{~km} \mathrm{~s}^{-1}, 2625 \mathrm{~kg} \mathrm{~m}^{-3}\right)$ and a lower diamond-shaped gabbro-anorthositic part (6.50 $\left.\mathrm{km} \mathrm{s}^{-1}, 2870 \mathrm{~kg} \mathrm{~m}^{-3}\right) . \Lambda$ reflective graben and horststructure within the batholith outlines the contact between the granitic and gabbro-anorthositic parts. Breaks in the reflections are interpreted as normal and reverse faults. 


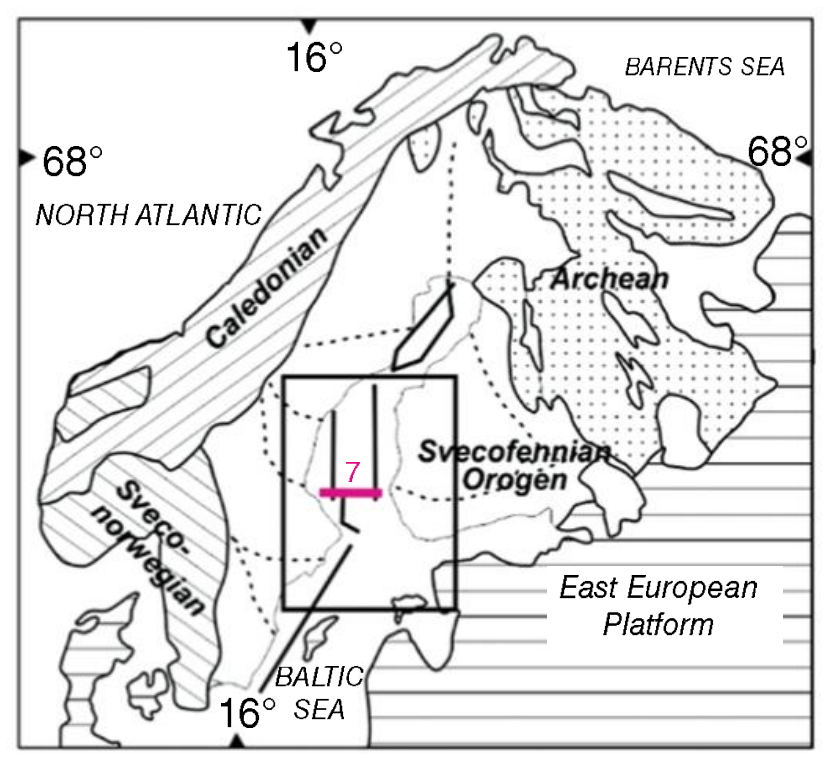

Figure 39.1a (top) BABEL7 line on a geological index map of Northern Europe. (bottom) BABEL7a lithological map of the study area after Kohonen and Rämö (2005).

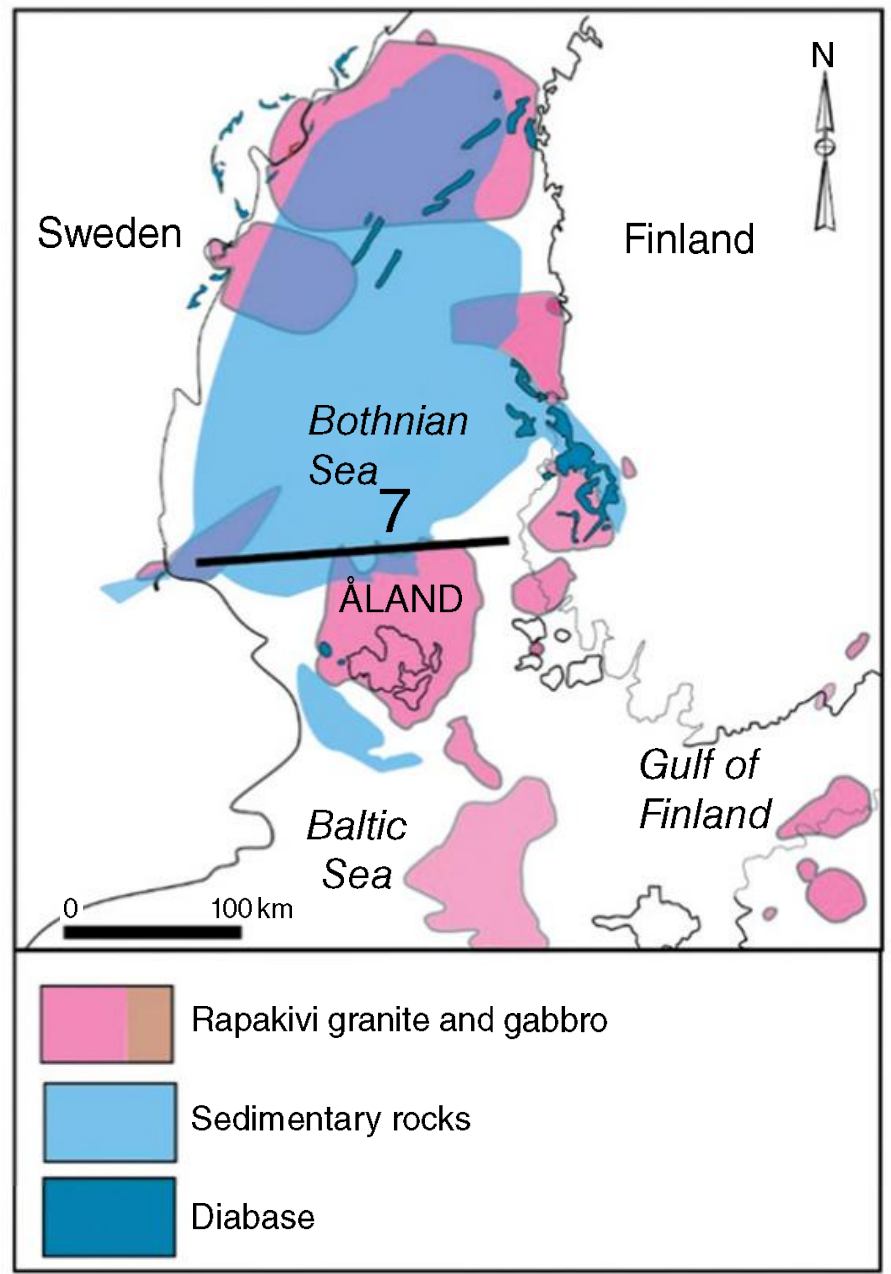




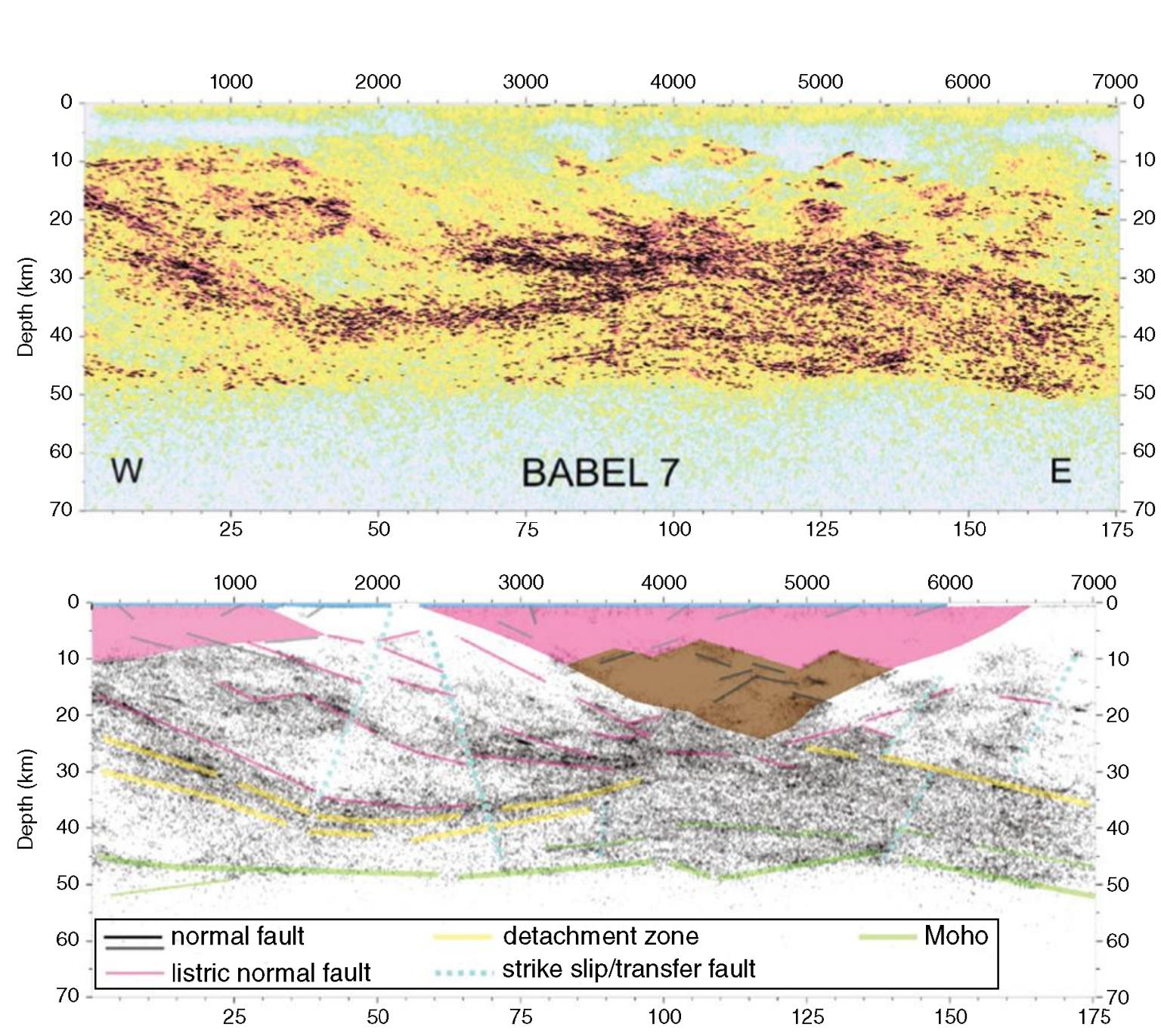

Figure 39.1b (top) A vertical seismic section along BABEL7 profile shown as an instantaneous amplitude section in colour scale overlain by an automatic line drawing. No vertical exaggeration. (bottom) A schematic geological line interpretation of BABEL7 profile on an instantaneous amplitude section in greyscale modified after Korja and Heikkinen (1995; 2005).

\section{References}

BABEL Working Group. 1993. Integrated seismic studies of the Baltic Shield using data in the Gulf of Bothnia region. Geophysical Journal International, 112, 305-324.

Korja, A. and Heikkinen, P.J. 1995. Proterozoic extensional tectonics of the central Fennoscandian Shield: Results from the Baltic and Bothnian Echoes from the Lithosphere experiment. Tectonics, 14, 504-517.

Korja, A. and Heikkinen, P. 2005. The Accretionary Svecofennian Orogen - insight from the BABEL profiles. Precambrian Research, 136, 241-268.
Korja, A., Lahtinen, R. and Nironen, M. 2006. The Svecofennian orogen: a collage of microcontinents and island arcs. In: Gee, D.G. and Stephenson, R.A. (eds) European Lithosphere Dynamics. Memoirs vol. 32, The Geological Society, London, pp.561-578.

Kohonen, J. and Rämö, O.T. 2005. Sedimentary rocks, diabases, and late Cratonic evolution. In: Lehtinen, $M$, Nurmi, P. and Rämö, O.T. (eds) Precambrian Geology of Finland - Key to the Evolution of the Fennoscandian Shield. Elsevier, Amsterdam, pp. 563-603. 